\title{
Application of Millimeter 3D Automatic Paving System in Highway Engineering Construction
}

\author{
Yi DONG ${ }^{1 \star}$, Jie $\mathrm{WANG}^{2}$, Yijia $\mathrm{MAO}^{3}, \mathrm{Hua}^{4}$ \\ 1 ChangZhou Communications Construction Administration Co.Ltd, ChangZhou, China \\ 2 Jiangsu Easttrans Intelligent Control Technology Group Co.Ltd , NanJing, China \\ 3 Jiangsu Easttrans Intelligent Control Technology Group Co.Ltd, NanJing, China \\ 4 Jiangsu Easttrans Intelligent Control Technology Group Co.Ltd, NanJing, China
}

*Corresponding Author: Yi DONG, Zidong 2\#, Maqun Street, Nanjing 210000, P.R. China, 419220471@qq.com

\begin{abstract}
:
In the construction of asphalt mixture pavement, there are many paving construction procedures, high requirements for machinery and personnel, unreasonable technology and so on. In this paper, the millimeter-scale 3D automatic paving control technology of asphalt mixture pavement is studied with an engineering example. From the analysis of the test results in the later stage of construction, it can be seen that the technology has achieved the goal of high precision paving, and the successful application of the technology provides valuable reference experience for similar asphalt concrete pavement construction in the future.

Keywords: Asphalt pavement; Millimeter grade; 3D paving control technology; Engineering application
\end{abstract}

\section{Introduction}

Due to its advantages of safe and comfortable driving, no dust on sunny days, no mud on rainy days and strong selfrepairing, asphalt concrete surface layer is widely used in the construction of high-grade highway in China, especially in the Eastern and Western regions, where the temperature difference between winter and summer is large $e^{[1]}$. However, at present, the early damage of asphalt concrete pavement is quite serious, and the fine construction of asphalt concrete pavement construction is particularly important, especially the paving link of asphalt concrete. Traditional pavement paving construction process is more, the requirements of machinery and personnel coordination, weather and other aspects are relatively high. In the design of turning, super elevation curve and other cross-slope changes, it is almost impossible to accurately set the hanging line $\mathrm{e}^{[2]}$. With the rapid development of science and technology, the concept of pavement 3D paving has gradually emerged. Through the application of advanced information technology such as high-precision positioning, intelligent sensors, three-dimensional modeling, data analysis and so on, the traditional roadbed construction machinery has eyes, has a sense, makes it can be accurately realized to control the smoothness in pavement constructionand, greatly simplifies the construction procedure. Especially, it reduces the measuring frequency, improves the benefit and controls the quality ${ }^{[3-4]} \cdot \mathrm{Lu}^{[5]}$ described the main equipment and technological process of 3D paving system, and analyzed the effect of 3D automatic paving technology applied to pavement construction based on the reconstruction and expansion project of liuzhou to nanning expressway. $\mathrm{Liu}^{[6]}$ introduced the construction process of 3D automatic paver control system, and compared the traditional construction technology, analyzed the advantages of 3D automatic paver system construction, providing valuable experience for the development of 3D paver technology.

\section{Principle of 3D paving technology}

\subsection{Technical principle}

Paver is the main machine used for laying structural layer and surface layer. During the construction of the automatic control system of 3D paver, the total station installed at the control point transmits the captured coordinates to the control box of the paver control system through the data radio in real time. After comparing the display control box with the design data, the elevation correction information is transmitted to the control box. At this time, the control box sends out instructions, and the hydraulic cylinder is driven 
by the hydraulic valve to produce a certain displacement of the traction arm. Change of the position of the left and right traction points cause the vertical movement of the ironing plate in the corresponding direction, which makes the filling change in slope and elevation, compensates for the fluctuation of the road surface, realizes the required smoothness of the road surface and meets the paving design requirements.

\section{2. system composition}

The high-precision paving system of $3 \mathrm{D}$ asphalt pavement mainly includes guiding system, control system and sensing system. The three systems are complementary and highly integrated to realize the automation, intellectualization and high precision of asphalt mixture paving construction. The hardware involved is shown in Table 1.

Table 1. List of equipment for 3D paving system

\begin{tabular}{|c|c|c|}
\hline System & Equipment name & Function description \\
\hline \multirow{2}{*}{ Guiding system } & $\begin{array}{l}\text { Intelligent Total } \\
\text { Station Robot }\end{array}$ & $\begin{array}{l}\text { The position of the target machine is measured and the position information of the } \\
\text { target machine is transmitted to the control box by digital radio. }\end{array}$ \\
\hline & Target & $\begin{array}{l}\text { Actively transmitting signals to the total station to facilitate the measurement of } \\
\text { prism 3-D coordinates by the total station }\end{array}$ \\
\hline \multirow{2}{*}{ Control system } & Gradient sensor & $\begin{array}{l}\text { The gradient sensor measures the cross slope and transmits the measurement result } \\
\text { to the control box through CAN bus. }\end{array}$ \\
\hline & Angle sensor & $\begin{array}{l}\text { The angle deviation information of receiving target positioning rod during paving is } \\
\text { collected relative to that of receiving target positioning rod during installation. }\end{array}$ \\
\hline \multirow{3}{*}{ Sensing system } & 2D Control box & $\begin{array}{l}\text { Display current elevation, design elevation, current slope, design slope and other } \\
\text { information. } \\
\text { The correction information provided by the three-dimensional control box is } \\
\text { submitted to the valve module through the CAN bus. }\end{array}$ \\
\hline & 3D Control box & $\begin{array}{l}\text { Load 3-D design files. } \\
\text { Display current elevation, design elevation, current slope, design slope and other } \\
\text { information. } \\
\text { Receive the data collected by each sensor, compare with the design data and send the } \\
\text { results to the } 2 \text {-D control box.. }\end{array}$ \\
\hline & Digital radio & Receiving Target Position Information Launched by Total Station \\
\hline
\end{tabular}

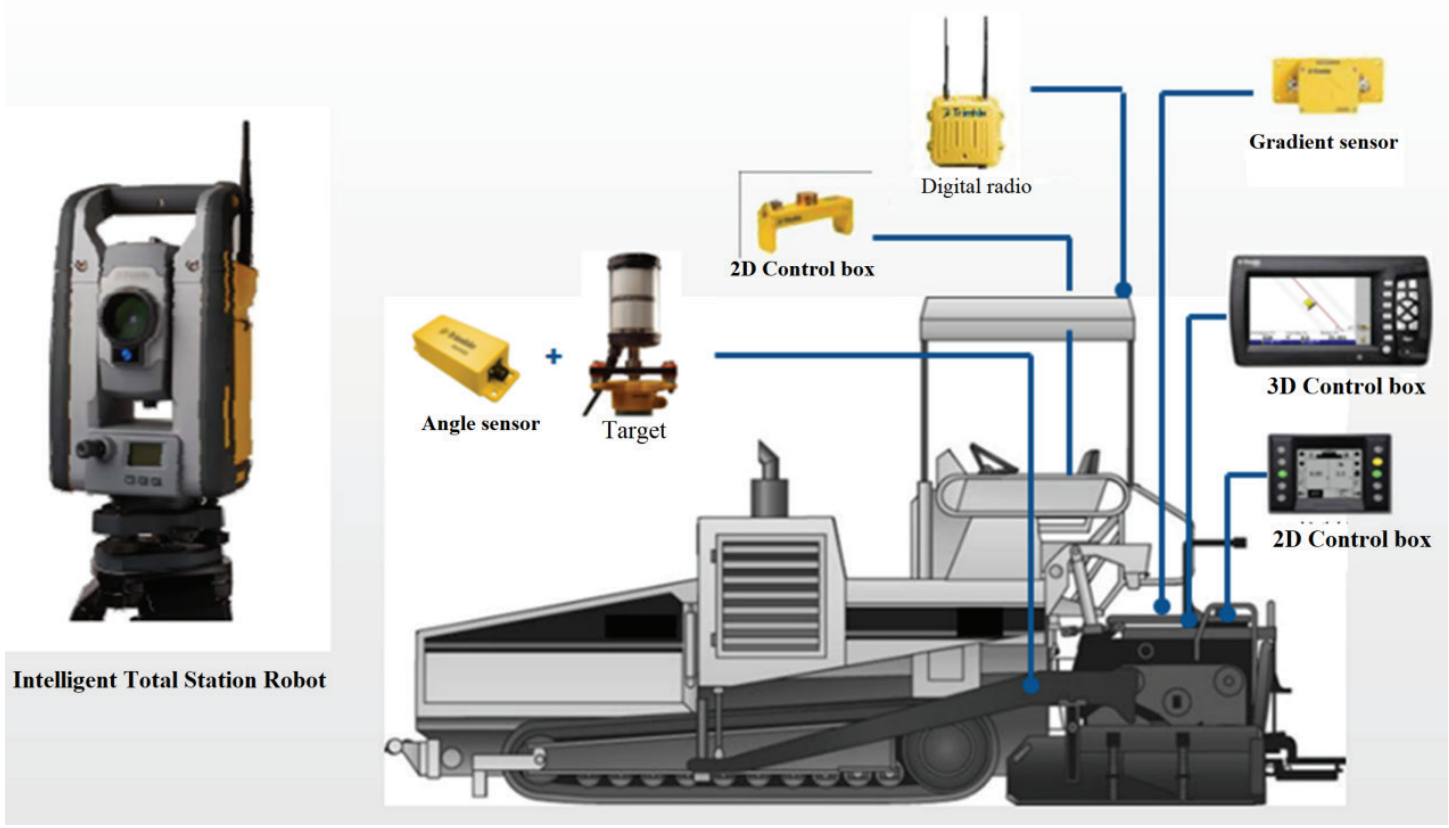

Figure 1. Schematic diagram of $3 \mathrm{D}$ paving system 


\section{Field implementation plan}

\subsection{Test scheme}

In order to compare the difference between $3 \mathrm{D}$ paving construction and traditional paving construction, the experiment is carried out in parallel with two methods. The specific requirements are as follows.

(1)system configuration

Paver 1 is equipped with 3-D paving control system and Paver 2 adopts the traditional paving control system.

(2)Programme description:
Paverl is equipped with 3D paving control system. Paver2 adopts the traditional 2D paving control mode. Figure 1 is the schematic test plan. The right side of paver 1 is equipped with a target, which is guided and controlled by the intelligent robot of total station; the left side is controlled by the cross slope sensor. There is no need to lay piles and hang wires or aluminium beams on both sides. The left side of paver2 uses the traditional 2D mode to refer to the paverl's paved surface to ensure the perfect joints; the right side still needs lay piles and hang wires / aluminium beam manually, and uses the traditional 2D control mode to pave.
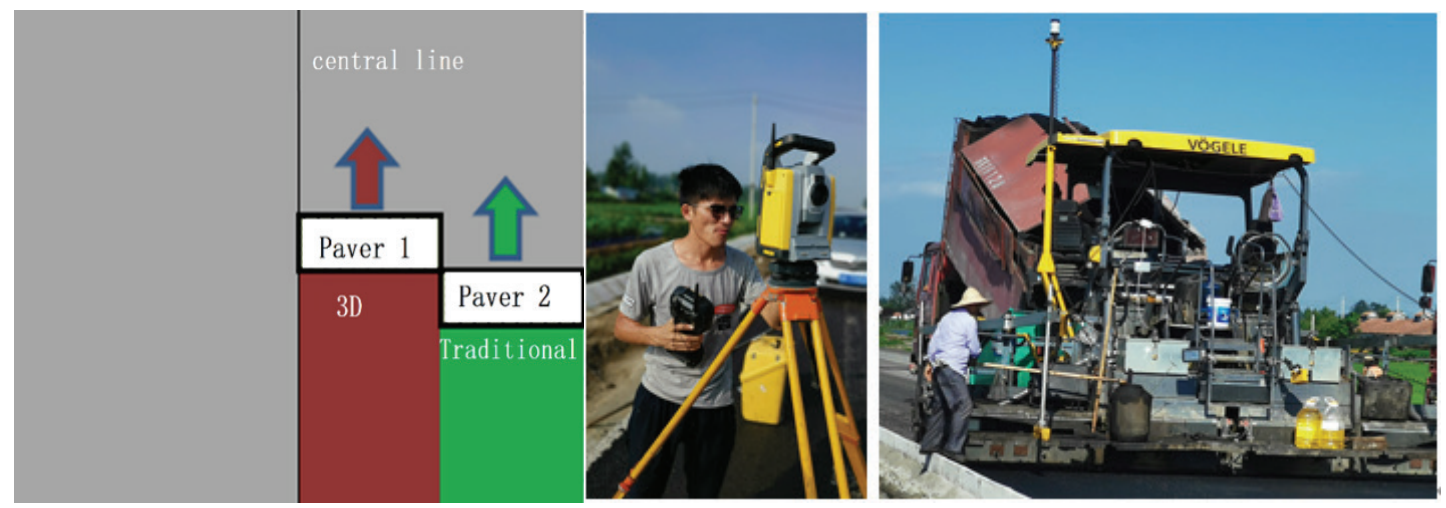

Figure 2. Schematic diagram of paving scheme

\subsection{The Collection Scheme of Test Data}

In order to compare the difference of personnel, efficiency and quality between traditional paving and 3D paving construction technology. According to each kilometer as a unit, the data acquisition section of 3D paving and the traditional construction section are one kilometer each, corresponding stake numbers are $\mathrm{K} 31+000-\mathrm{K} 32+000$ and $\mathrm{K} 32+000-\mathrm{K} 33+00$ in the northern half. The data acquisition requirements are as follows.

\subsubsection{Personnel data}

According to the statistics of manual consumption in this test section, the time consumption of labor workers (auxiliary workers), mechanical operators (drivers of pavers), surveyors (engineers and technicians), and testers was collected under the two conditions of $3 \mathrm{D}$ paving construction and traditional construction.

\subsubsection{Line detection}

After the field rolling, the gradient of the center of the paving area is measured by total station in the $3 \mathrm{D}$ paving area and the traditional paving area. The data acquisition density is 100 meters.

\subsubsection{Data Acquisition of Quality Inspection}

(1) thickness

Total Station Measuring Method: Total Station is used to measure the elevation difference of the same point before and after paving construction. Six points are collected for each section of 10 meters, three points for the construction section of the left paver and three points for the construction section of the right paver. Thickness nephogram of 3D paving area and traditional paving area is generated.

Core drilling sampling method: Within the range of $\mathrm{K} 32+000-\mathrm{K} 33+00,6$ points are collected for each section of 200 meters using core drilling machine, which are 3 points for the construction section of the left paver and 3 points for the construction section of the right paver. Within $\mathrm{K} 31+000-\mathrm{K} 32+000$, in the construction area of the left paver, there is a section every 200 meters and three points for each section.

(2) Compaction degree

Marking the core samples obtained from the drill core, and measuring the compactness of each core sample by Marshall method.

(3) Planeness

Measuring the pavement smoothness of 3D paving section and traditional construction section by eight-wheel instrument.

\section{Analysis of experimental data}

\subsection{Personnel data}

According to the statistics of construction site, there are seven types of work involved in asphalt pavement construction, namely: paver mechanical driver, surface treatment worker, joint treatment worker, road surface treatment worker, measurement control worker, quality inspector, management personnel. From Table 2, it can be seen that the number of workers required by each paver is 12 by using $3 \mathrm{D}$ paving construction technology, and 20 by using traditional paving construction technology. Therefore, the use of 3D paving technology can save $40 \%$ 
of human resources.

\subsection{Line detection}

The longitudinal gradient of the center line of the left paving area of $\mathrm{K} 31+000-\mathrm{K} 32+000$ and $\mathrm{K} 32+000-\mathrm{K} 33+00$ is obtained by total station. The traditional paving area $\mathrm{K} 31+000-\mathrm{K} 32+000$ obtains 10 data of a vertical slope every $100 \mathrm{~m}$, while the $3 \mathrm{D}$ paving area $\mathrm{K} 32+000-\mathrm{K} 33+000$ obtains
10 data of a vertical slope every $100 \mathrm{~m}$. The specific data are shown in Table 3. It can be seen from the table that the variation coefficient $\mathrm{CV}$ of longitudinal slope is -0.54 and that of traditional paving construction technology is -1.43 . It shows that the $3 \mathrm{D}$ paving construction technology can better control the line type and the slope control is more accurate.

Table 2. Statistics of labor consumption

\begin{tabular}{cccc}
\hline number & Personnel situation & $\begin{array}{c}\text { 3D paving / number of } \\
\text { people }\end{array}$ & $\begin{array}{c}\text { Traditional paving / number of } \\
\text { people }\end{array}$ \\
\hline 1 & paver mechanical driver & 3 & 3 \\
2 & surface treatment worker & 2 & 3 \\
3 & joint treatment worker & 1 & 3 \\
4 & road surface treatment worker & 1 & 4 \\
\hline 5 & measurement control worker & 2 & 1 \\
\hline 6 & quality inspector, & 1 & 3 \\
\hline 7 & management personnel & 2 & 20 \\
\hline
\end{tabular}

Table 3. data of line detection

\begin{tabular}{|c|c|c|c|c|}
\hline \multirow{2}{*}{ number } & \multicolumn{2}{|c|}{ traditional paving construction } & \multicolumn{2}{|c|}{$3 \mathrm{D}$ paving construction } \\
\hline & stake number & Longitudinal gradient $(\%)$ & stake number & Longitudinal gradient $(\%)$ \\
\hline 1 & $\mathrm{~K} 31+000$ & $0.02 \%$ & $\mathrm{~K} 32+000$ & $-0.14 \%$ \\
\hline 2 & $\mathrm{~K} 31+100$ & \multirow{2}{*}{$-0.10 \%$} & $\mathrm{~K} 32+100$ & \multirow{2}{*}{$-0.14 \%$} \\
\hline 3 & $\mathrm{~K} 31+200$ & & $\mathrm{~K} 32+200$ & \\
\hline 4 & $\mathrm{~K} 31+300$ & $-0.01 \%$ & $\mathrm{~K} 32+300$ & $-0.14 \%$ \\
\hline 5 & $\mathrm{~K} 31+400$ & \multirow{2}{*}{$-0.04 \%$} & $\mathrm{~K} 32+400$ & \multirow{2}{*}{$-0.12 \%$} \\
\hline 6 & $\mathrm{~K} 31+500$ & & $\mathrm{~K} 32+500$ & \\
\hline 7 & $\mathrm{~K} 31+600$ & $0.01 \%$ & $\mathrm{~K} 32+600$ & $-0.05 \%$ \\
\hline 8 & $\mathrm{~K} 31+700$ & \multirow{2}{*}{$-0.21 \%$} & $\mathrm{~K} 32+700$ & \multirow{2}{*}{$-0.04 \%$} \\
\hline 9 & $\mathrm{~K} 31+800$ & & $\mathrm{~K} 32+800$ & \\
\hline 10 & $\mathrm{~K} 31+900$ & $-0.03 \%$ & $\mathrm{~K} 32+900$ & $-0.07 \%$ \\
\hline \multirow{3}{*}{11} & \multirow{3}{*}{$\mathrm{K} 32+000$} & $0.00 \%$ & \multirow{3}{*}{$\mathrm{K} 33+000$} & $-0.09 \%$ \\
\hline & & $-0.02 \%$ & & $-0.06 \%$ \\
\hline & & $-0.15 \%$ & & $-0.01 \%$ \\
\hline \multirow{3}{*}{$\begin{array}{c}\text { statistical } \\
\text { analysis }\end{array}$} & standard deviation SD & $0.08 \%$ & standard deviation SD & $0.05 \%$ \\
\hline & average value & $-0.05 \%$ & average value & $-0.09 \%$ \\
\hline & Coefficient of variation $\mathrm{CV}$ & -1.43 & Coefficient of variation $\mathrm{CV}$ & -0.54 \\
\hline
\end{tabular}

\subsection{Data Acquisition of Quality Inspection}

\subsection{1 thickness}

(1) Method of total station measurement

Figure 2 shows the thickness of asphalt pavement obtained by total station. From the figure, it can be seen that the thickness of 3D paving construction area is uniform and the error is controlled within $1 \mathrm{~cm}$. In the traditional construction area, the paving is too thick or thin in some areas. The blue area in the figure is over $1 \mathrm{~cm}$ thick, and the red area is over $1 \mathrm{~cm}$ thin. 


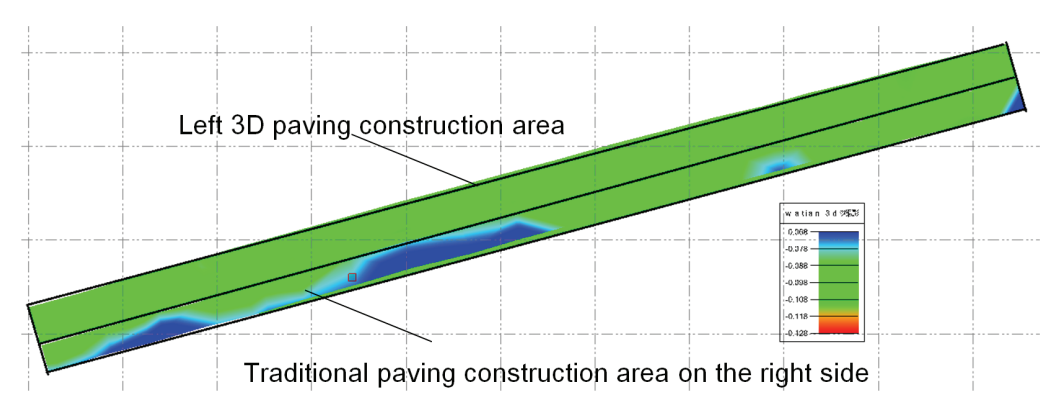

Nephogram of 3D paving thickness $(\mathrm{K} 32+000-\mathrm{k} 33+000)$

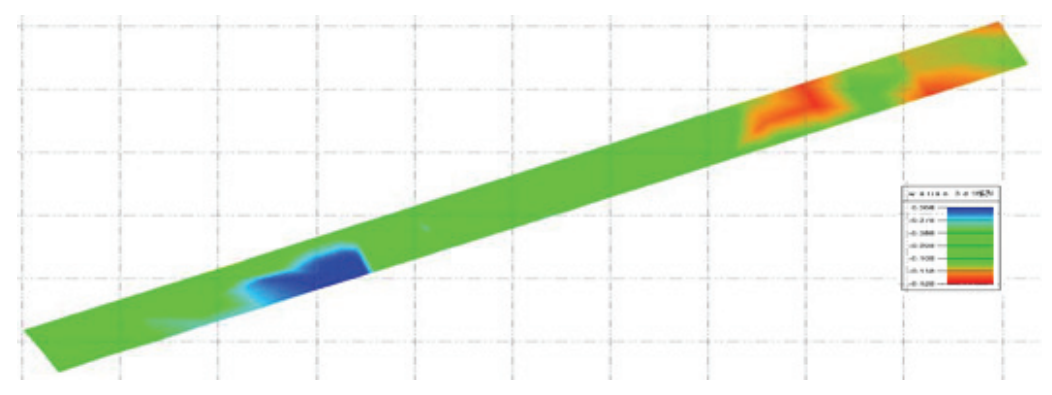

Nephogram of traditional paving thickness $(\mathrm{K} 31+000-\mathrm{k} 32+000)$

Figure 3. Thickness nephogram

(2) Method of core sampling

According to the core sampling detection scheme, drilling cores were sampled in the field, and the height of each core sample was measured by vernier caliper. The average thickness of each core sample was taken as the layer thickness of the sampling point. A total of 30 sets of data were obtained. The specific data are shown in Table 4. It can be seen from the table that the average thickness of 3D paving construction technology and traditional paving construction technology are $79.3 \mathrm{~mm}$ and $83.3 \mathrm{~mm}$, respectively, which meet the requirements of the specifications, but the traditional paving thickness is too large, resulting in waste of asphalt mixture and increasing construction costs. From the aspect of thickness uniformity, the standard deviation of thickness between 3D paving construction technology and traditional paving construction technology is 1.0 and 6.5 , respectively, which indicates that the performance of thickness control of 3D paving construction technology is much higher than that of traditional paving technology.

4.3.2 Compaction degree

By using Marshall method, the core samples obtained from field drilling are tested for compactness. A total of 30 sets of data are obtained. The specific data are shown in Table 5. It can be seen from the table that the representative values of compactness of $3 \mathrm{D}$ paving construction technology and traditional paving construction technology are more than 98 , and the compaction quality is qualified. However, the standard deviation of compactness in 3D paving construction area is 0.9 , which is much smaller than the standard deviation of compactness in traditional paving construction area of 2.6. This is due to 3D paving technology, the control thickness is more uniform, and the compaction quality is more uniform under the same rolling conditions.

Table 4. Data of Core Sampling Thickness Detection

\begin{tabular}{|c|c|c|c|c|c|}
\hline \multicolumn{3}{|c|}{ 3D Paving Construction } & \multicolumn{3}{|c|}{ Traditional paving construction } \\
\hline \multicolumn{2}{|c|}{ Location of measuring points } & \multirow[b]{2}{*}{ thickness ( $\mathrm{mm})$} & \multicolumn{2}{|c|}{ Location of measuring points } & \multirow[b]{2}{*}{ thickness $(\mathrm{mm})$} \\
\hline stake number & $\begin{array}{c}\text { Horizontal distance } \\
(\mathrm{m})\end{array}$ & & stake number & $\begin{array}{c}\text { Horizontal distance } \\
(\mathrm{m})\end{array}$ & \\
\hline \multirow{3}{*}{$\mathrm{K} 32+900$} & 2 & 78.5 & \multirow{3}{*}{$\mathrm{K} 31+900$} & 2 & 81.5 \\
\hline & 4 & 78.6 & & 4 & 85.2 \\
\hline & 6 & 79.6 & & 6 & 86.9 \\
\hline \multirow{3}{*}{$\mathrm{K} 32+700$} & 2 & 80.1 & \multirow{3}{*}{$\mathrm{K} 31+700$} & 2 & 91.6 \\
\hline & 4 & 79.3 & & 4 & 90.3 \\
\hline & 6 & 78.9 & & 6 & 95.7 \\
\hline
\end{tabular}




\begin{tabular}{|c|c|c|c|c|c|}
\hline \multicolumn{3}{|c|}{ 3D Paving Construction } & \multicolumn{3}{|c|}{ Traditional paving construction } \\
\hline \multicolumn{2}{|c|}{ Location of measuring points } & \multirow[b]{2}{*}{ thickness $(\mathrm{mm})$} & \multicolumn{2}{|c|}{ Location of measuring points } & \multirow[b]{2}{*}{ thickness $(\mathrm{mm})$} \\
\hline stake number & $\begin{array}{c}\text { Horizontal distance } \\
(\mathrm{m})\end{array}$ & & stake number & $\begin{array}{c}\text { Horizontal distance } \\
(\mathrm{m})\end{array}$ & \\
\hline \multirow{3}{*}{$\mathrm{K} 32+500$} & 2 & 78.6 & \multirow{3}{*}{$\mathrm{K} 31+500$} & 2 & 73.5 \\
\hline & 4 & 79.3 & & 4 & 84.4 \\
\hline & 6 & 80.4 & & 6 & 78.4 \\
\hline \multirow{3}{*}{$\mathrm{K} 32+300$} & 2 & 79.9 & \multirow{3}{*}{$\mathrm{K} 31+300$} & 2 & 76.6 \\
\hline & 4 & 80.4 & & 4 & 75.9 \\
\hline & 6 & 79.3 & & 6 & 88.6 \\
\hline \multirow{3}{*}{$\mathrm{K} 32+100$} & 2 & 80.2 & \multirow{3}{*}{$\mathrm{K} 31+100$} & 2 & 82 \\
\hline & 4 & 79.9 & & 4 & 82.9 \\
\hline & 6 & 76.5 & & 6 & 75.8 \\
\hline \multicolumn{2}{|c|}{ data type } & $\begin{array}{c}\text { Number of } \\
\text { measurements } \\
\text { (points) }\end{array}$ & $\begin{array}{c}\text { Prescribed } \\
\text { value }(\mathbf{m m})\end{array}$ & $\begin{array}{c}\text { average } \\
\text { value }(\mathbf{m m})\end{array}$ & $\begin{array}{l}\text { standard } \\
\text { deviation }\end{array}$ \\
\hline \multicolumn{2}{|c|}{ 3D Paving Construction } & 15 & 80 & 79.3 & 1.0 \\
\hline \multicolumn{2}{|c|}{ Traditional paving construction } & 15 & 80 & 83.3 & 6.5 \\
\hline
\end{tabular}

Table 5. Data for compactness testing

\begin{tabular}{|c|c|c|c|c|c|}
\hline \multicolumn{3}{|c|}{ 3D Paving Construction } & \multicolumn{3}{|c|}{ Traditional paving construction } \\
\hline \multicolumn{2}{|c|}{ Location of measuring points } & \multirow{2}{*}{$\begin{array}{c}\text { Compaction degree } \\
(\%)\end{array}$} & \multicolumn{2}{|c|}{ Location of measuring points } & \multirow[b]{2}{*}{ Compaction degree(\%) } \\
\hline stake number & $\begin{array}{c}\text { Horizontal } \\
\text { distance }(\mathrm{m})\end{array}$ & & stake number & $\begin{array}{c}\text { Horizontal } \\
\text { distance }(\mathrm{m})\end{array}$ & \\
\hline \multirow{3}{*}{$\mathrm{K} 32+900$} & 2 & 98.5 & \multirow{3}{*}{$\mathrm{K} 31+900$} & 2 & 98.0 \\
\hline & 4 & 100.6 & & 4 & 101.1 \\
\hline & 6 & 98.5 & & 6 & 101.5 \\
\hline \multirow{3}{*}{$\mathrm{K} 32+700$} & 2 & 100.7 & \multirow{3}{*}{$\mathrm{K} 31+700$} & 2 & 100.2 \\
\hline & 4 & 98.9 & & 4 & 99.1 \\
\hline & 6 & 99.5 & & 6 & 98.9 \\
\hline \multirow{3}{*}{$\mathrm{K} 32+500$} & 2 & 98.1 & \multirow{3}{*}{$\mathrm{K} 31+500$} & 2 & 97.6 \\
\hline & 4 & 99.9 & & 4 & 98.7 \\
\hline & 6 & 100.9 & & 6 & 99.2 \\
\hline \multirow{3}{*}{$\mathrm{K} 32+300$} & 2 & 98.8 & \multirow{3}{*}{$\mathrm{K} 31+300$} & 2 & 100.2 \\
\hline & 4 & 100.0 & & 4 & 98.3 \\
\hline & 6 & 100.4 & & 6 & 99.9 \\
\hline \multirow{3}{*}{$\mathrm{K} 32+100$} & 2 & 100.0 & \multirow{3}{*}{$\mathrm{K} 31+100$} & 2 & 99.6 \\
\hline & 4 & 98.5 & & 4 & 101.0 \\
\hline & 6 & 100.4 & & 6 & 108.6 \\
\hline data type & $\begin{array}{c}\text { Number of } \\
\text { measurements } \\
\text { (points) }\end{array}$ & $\begin{array}{l}\text { Prescribed } \\
\text { value }(\%)\end{array}$ & $\begin{array}{c}\text { average } \\
\text { value }(\%)\end{array}$ & $\begin{array}{l}\text { standard } \\
\text { deviation }\end{array}$ & $\begin{array}{l}\text { Representative } \\
\text { value }(\%)\end{array}$ \\
\hline $\begin{array}{c}\text { 3D Paving } \\
\text { Construction }\end{array}$ & 15 & 98 & 99.6 & 0.9 & 99.1 \\
\hline $\begin{array}{c}\text { Traditional } \\
\text { paving } \\
\text { construction }\end{array}$ & 15 & 98 & 100.1 & 2.6 & 98.9 \\
\hline
\end{tabular}




\subsubsection{Planeness}

After the construction of asphalt pavement completed, the effects of $3 \mathrm{D}$ paving and traditional paving are tested by eight-wheel planeness meter. The results are shown in Table 6.

Table 6 shows that the planeness of asphalt pavement is less than the allowable value $(1.2 \mathrm{~mm})$ and the qualified rate is $100 \%$ using $3 \mathrm{D}$ paving technology. The planeness of asphalt pavement construction fluctuates greatly using traditional paving technology, the maximum value is 1.79 $\mathrm{mm}$, which is larger than the allowable value, and the qualified rate is only $61 \%$. This indicates that the $3 \mathrm{D}$ paving technology can improve the planeness of asphalt pavement.

Table 6. Testing data of compactness

\begin{tabular}{cccccccc}
\hline Technology & stake number & $\begin{array}{c}\text { Number of } \\
\text { tests }\end{array}$ & $\begin{array}{c}\text { Allowable } \\
\text { value }(\mathrm{mm})\end{array}$ & $\begin{array}{c}\text { average value } \\
(\mathrm{mm})\end{array}$ & $\begin{array}{c}\text { Maximum } \\
\text { value } \mathrm{mm})\end{array}$ & $\begin{array}{c}\text { minimum } \\
\text { value }\end{array}(\mathrm{mm})$ & $\begin{array}{c}\text { Pass rate } \\
(\%)\end{array}$ \\
\hline $\begin{array}{c}\text { 3D paving } \\
\text { construction } \\
\begin{array}{c}\text { Traditional paving } \\
\text { construction }\end{array}\end{array}$ & $\mathrm{K} 32+000-\mathrm{K} 33+00$ & 24 & 1.2 & 0.58 & 0.71 & 0.33 & 100 \\
\hline
\end{tabular}

\section{Conclusion}

3D paving technology does not need to lay piles and erect aluminium beams to greatly reduce construction survey work. Site can be put into work quickly. Digital construction can reduce about $40 \%$ of surveying and assistant personnel, make construction site more concise and efficient, reduce potential safety hazards, realize millimeter accuracy level control and improve paving accuracy by about $30 \%$, the intelligent paver does not need the operator to control the ironing elevation and cross slope. Compared with the traditional construction, the work efficiency can be increased by about $50 \%$. It reduces the dependence on the roughness of the base and ensures the accuracy of the pavement in the error range to the greatest extent.

\section{References}

[1] Wang Jiahui. Early Problems of Asphalt Concrete Pavement and Preventive Measures [J]. Highway Engineering, 2012(17):63-65.

[2] Guo Xiaohong, Du Zhengde, Guo Jiaying. Theory and
Practice in the Mechanical Construction System of the Asphalt Paving (VII)—-The Computer Simulation of Mechanical Construction System[J]. JOURNAL OF CHONGQING JIAOTONG INSTITUTE, 1996.

[3] Lei Xiaolei, Li Gang. 3 Applied Research of 3D Paving Control Technology in Asphalt Pavement Works [J]. Road \& Traffic Engineering, 2018(5):20-24..

[4] Zu Mingxing. Research on 3D Intelligent Paving Application of Asphalt Concrete Pavement [J]. Road Engineering, 2018, 136(11):17-20.

[5] Lu Qiaoyu. Application Analysis of 3DTechnology Pavement Construction in Highway Engineering[J]. Western China Communications Science \& Technology, 2018.

[6] Liu Fuxu. Discussion on the Application of 3D Automated Paving System in Highway Engineering Construction[J]. Western China Communications Science \& Technology, 2018. 